\title{
Study on the Practice of Phonics in English Vocabulary Teaching for Primary School Students
}

\author{
Huanhuan $\operatorname{Ren}^{1, a^{*}}$, Chi Ma ${ }^{2, b}$ \\ ${ }^{1}$ Teaching and Research Institute of Foreign Languages, Bohai University, Jinzhou 121013, China \\ 2 Jinzhou Institute of Forestry Research, Jinzhou Forestry Bureau, Jinzhou 121013, China \\ arenhuanhuan2014@163.com, ${ }^{\mathrm{b}}$ machi2014@tom.com
}

Keywords: Phonics; English teaching; Primary school students

\begin{abstract}
Phonics exerts considerable influence on contemporary language education and the most of the society begin to pay attention to phonics and actively participate in this educational reform. It has been aruged that phonics instruction for the primary school students may be supported and underpined by the theory of children's cognitive development and critical period hypothesis. Whilst carrying out practice of phonics in English vocabulary teaching for the primary school students, instructros are expected to take four main things of phonics instruction into account, i.e. quality textbook for primary school students, various pedagogical activities for primary school students, continuous phonics learning for primary school students, and much authentic reading opportunities for primary school students, so as to gain deeper insights into the teaching of phonics. It's hoped that this research provides a useful reference for future phonics instruction practice among young language students.
\end{abstract}

\section{Introduction}

For decades now, the teaching and learning of phonics has been the main subject of language learning across the globe, and the most of the society begin to pay attention to phonics and actively participate in this educational reform. It has been argued that failing to provide students with explicit and systematic phonics teaching seem to leave important learning up to students to figure out for themselves, which often results in frustration, disengagement and underachievement on the part of the learner. Thus how to implement phonics instruction among primary school learners? How to provide a range of learning strategies to develop students' phonics knowledge and skills? Are instructors getting ready to put systematic phonics teaching into action among young students in primary school? In the thesis, we attempt to argue for history and development of phonics, theoretical framework of phonics instruction and the practice of phonics in English vocabulary teaching for primary school students, so as to gain deeper insights into the teaching of phonics. This paper is a summary of this research work, which hopefully provides a useful reference for future phonics instruction practice among young language students.

\section{History and Development of Phonics}

The History of Phonics. The term phonics during the 19th century and into the 1970s was used as a synonym of phonetics. The use of the term in reference to the method of teaching is dated to 1901 by the Oxford English Dictionary [1]. Phonics derived from the Roman text The Doctrine of Littera, which described that a letter consisted of a sound, a written symbol and a name[2]. Phonics teaching could trace back to the reform of the Catholic Church. In the 16th century, Latin was believed the only pure language to worship God, and the other languages were prohibited in the church. In order to make all the believers understand, the Bible was translated into English. Therefore, an easy and singular way of learning English, named phonics, was invented to teach English[3]. In 1790s, Phonics was widely applied in American reading instruction. However, with the fad of the whole-word method from the late 1930s to 1940s, phonics was at the center of controversy[3]. In 1955, Rudolf 
Flesch firmly advocated a return concern to phonics. In North America, phonics method as a new model of second language teaching has become the prevailing teaching method since the 1990s. Phonics is being preceded in a great many of English-speaking countries, such as Canada, Australia, UK, Singapore later on [3].

The Approaches to Phonics. There are several different methods for teaching phonics: synthetic phonics, analytic phonics and analogy phonics. Synthetic phonics uses a part-to-whole approach that teaches students letter-sound (grapheme-phoneme) relationships in a clearly defined incremental sequence [4]. Students are taught small groups of letter sounds during short, brisk daily sessions so they can begin blending (synthesizing) when reading and segmenting letter sounds in words when spelling [7]. It follows the bottom-up model and teaches children to "convert letters into sounds and then blend the sounds into word." [5] Overall, many researchers are favor of the synthetic phonics instruction. The analytic phonics is a type of whole-to-part approach, which teaches children to analyze letter-sound relations once a word is identified. It's also called implicit phonics. Learners are encouraged to find out letter-sound correspondence themselves, as it starts at the word level and begins from words that children already learned. Analogy phonics teaches students to use parts of written words they already know to identify new words [4]. It, however, should be taught after children have been equipped with phonetic knowledge and other decoding approaches. In sum, each method of phonics is drawn by instructors on at different points in teaching and which method to be adopted is depending on the instructional purpose and context in English language learning.

Phonics for EFL Learners. It's evident that children in those English-speaking countries usually start to receive phonics training when they are in the elementary school. And it's the dominant method to teach and learn the pronunciation and words. Then how about phonics for learners in non-English-speaking countries? It's found that researchers and educators agreed on the idea of phonics and discovered phonics instruction as an English teaching instruction not only for young native speakers but also for EFL learners. Lizzy discussed in her paper that phonics instruction can help EFL students to improve their listening and speaking skills, together with their pronunciation and intonation[6]. In light of a large body of research on the effectiveness of phonics in EFL learning, phonics instruction was embraced by EFL learners in China. Taiwan and Hong Kong firstly introduced phonics to English language teaching in 2000, and have spread it on a large scale since then. In 2012, National English Curriculum Standard published by the Department of Education claimed that students should learn the new words by phonics. And there was a part of phonics knowledge in the students' textbooks[3]. From above, we can see teaching phonics obviously isn't an easy job, but it's probably an important one, and there is a global trend toward the incorporation of phonics in EFL instruction among young English language learners.

\section{Theoretical Framework of Phonics Instruction for the Primary School Students}

Children's Cognitive Development. Are children capable of learning foreign language? What are children capable of learning at various stages in their development? Theory of cognitive development was devised by French psychologist Jean Piaget when he published his groundbreaking theory on cognitive development in children. Piaget proposed four stages of cognitive development: the sensor motor, preoperational, concrete operational and formal operational period, with each stage building upon the last and characterized by higher levels of sophistication and thought [7]. It focuses on a child's development in terms of information processing, conceptual resources, perceptual skill, language learning, and other aspects of brain development and cognitive psychology compared to an adult's point of view. It's further found that, attention, short-term memory, and long-term memory are developing between the ages of 2 and 5; Auditory processing, which is critical for good reading skills, is developing between the ages of 5 and 7; Logic and reasoning also becomes more established during after 5 years of age as a child becomes better able to make connections between ideas [8]. Piaget's stages were groundbreaking as his theory of cognitive development underpinned most kindergartens and primary schools. Before his influential theory changed the way people viewed childhood 
development, it was believed that babies were without cognition until they were old enough to develop language [8].

Critical Period Hypothesis. The critical period hypothesis claims that there is an ideal time window to acquire language in a linguistically rich environment, after which further language acquisition becomes much more difficult and effortful. Lenneberg proposed that language is the results of the brain and the development of linguistic competence is dominated strictly by physiological basis of human beings [9]. In critical period after children born, the brain of human being has strong plasticity and language acquisition can occur more naturally and easily. After that, most people's brain would have been lateralized gradually, meanwhile, the brains had fully grown up to maturity [9]. As to the time to teach phonics, some expects hold that it should start at the age of four or five. However, there is much debate over the timing of the critical period with respect to ESL or EFL. A great amount of scholars advise that the second language learning in their country should begin as early as the child is four. However, some scholar argued that there is no single magic age for EFL learning, and both older and younger learners are able to achieve advanced levels of proficiency in an EFL environment. In sum, as Bialystok and Hakuta concluded on reviewing the published material, second-language learning (or EFL) is not necessarily subject to biological critical periods, but on average, there is a continuous decline in ability to learn with age[10].

\section{The Practice of Phonics in English Vocabulary Teaching for the Primary School Students}

Quality Textbook for Primary School Students. As phonics instruction is becoming a fad in foreign language teaching, a large body of textbooks with different qualities abounds in the market. Although many books written for young children have a high degree of repetition anyway, how to choose an appropriate and effective phonics textbook is the still the first key task faced by language learners. Firstly, the use of decodable texts is sometimes advocated to reinforce phonics learning. Phonics should be taught and practiced to a level where decoding becomes habitual and automatic, and students need frequent opportunities to practice and apply their developing knowledge through the use of textbooks. Besides, well-structured texts of the type used in early years' classrooms are preferable. Teaching phonics in an effective sequence will significantly influence the rate at which students successfully acquire phonics knowledge and skills and facilitate student learning by, for example, minimizing potential confusion. An effective sequence for teaching phonics may build from simple to complex, common to uncommon and known to unknown. Lastly, instructors should think very carefully about the diversity of textbooks and this diversity provides substantial benefits for the students themselves and for the wider community. In brief, several things are anticipated to be considered in primary school whistling selecting and weighing different phonics textbooks, so that students can ultimately achieve optimum cognitive effects in phonics learning.

Various Pedagogical Activities for Primary School Students. Phonics learning is never an easy job which involves a large amount of relationship between letters and sounds. If one is delving into phonic learning, it's better for him or her to find the joy and fun through engaging in various pedagogical activities. High quality phonics teaching involves the use of auditory, visual and kinesthetic activities that encourages learners to activate as many of their senses as possible. Activities could involve students moving their bodies to make letter shapes, manipulating magnetic letters to make words, tracing letters and words with fingers in the air or with sticks in sand, tapping out phonemes, writing letters with crayons, pencils, chalk, whiteboard markers or using a computer to create and manipulate words and texts [4]. Students will discover phonics knowledge simply by doing lots of hands on, fun activities, and this discovery part is an important component of phonics learning for primary school students in spite of the fact phonics instruction is expected to be in an explicit and direct way. Moreover, instructors should plan for and differentiate phonics instruction to meet students' different learning needs, as everyone has different cognitive strengths. For example, some people have exceptionally strong memory skills, while other people excel in logic and reasoning. All in all, instructors should provide opportunities for students to learn and demonstrate their phonics 
knowledge in different ways so as to potentially contribute to them developing and extending their vocabularies and general knowledge.

Continuous Phonics Learning for Primary School Students. The concept of phonics learning is a general idea that one should understand the fundamentally alphabetic nature of our writing system and, through that understanding, to internalize the correspondences between frequent spelling patterns and the speech patterns (the words, syllables, and phonemes) that these spelling represent[11], but that's not enough. Or say, the knowledge of particular groups of letter-sound correspondences is only one part of learning phonics by primary school students. Instructors are also anticipated to make connections between students' experiences and the learning of new phonics knowledge and even provide challenge for all students after the formal period of phonics learning. Few people understand the impact of continuous phonics practice in learning. That's why many learners stop at the initial stage of acquiring phonics knowledge and turn to other aspects of language learning, for example grammars, which turns out to be of low efficiency in language learning. It's argued that programs that focus too much on the teaching of letter-sound relationships and not enough on putting them to use are unlikely to be very effective. In sum, although phonics encourages teachers to allow kindergarten students to begin blending and segmenting words as soon as possible, persistent learning and practice should be pursued and sought by phonics students so that they are given more opportunities to apply and utilize phonics knowledge in learning.

Much Authentic Reading Opportunities for Primary School Students. Despite the fact that phonics instruction is never a total reading program, phonics training can't separate from a large body of reading exercises. Phonics needs to be integrated into other parts of a literacy session and into learning in other learning areas. As it's stated in National Inquiry into the Teaching of Literacy formulated by Australia, educators must keep the end (original emphasis) in mind and ensure that children understand the purpose of learning letter-sounds and are able to apply their skills in their daily reading and writing activities in implementing systematic phonics instruction[12]. It's argued that the more students are provided with scaffolded opportunities to practice their phonics learning in authentic reading and writing contexts, the more successful they will be in applying and transferring this knowledge. Equally, phonics, in return, should be taught explicitly and systematically as part of a balanced and integrated literacy program. As Center notes, the systematic, explicit teaching of phonics is a necessary condition but not a sufficient condition for the teaching of reading[13]. Since reading essentially involves two basic and complementary processes: learning how to decipher print and understanding what the print means, an integrated approach to reading instruction is mandatory. To sum up, extensive and authentic reading is more helpful in improving children's phonics knowledge and skills through an integrated approach provided by English language teachers.

\section{Conclusion}

It has been concluded that phonics exerts considerable influence on contemporary language education. There are some truth in the fact that phonics instruction for the primary school students are supported and underpined by the theory of children's cognitive development and critical period hypothesis. Whilst carrying out practice of phonics in English vocabulary teaching for the primary school students, instructros are expected to take four main things of phonics instruction into account, i.e. quality textbook for primary school students, various pedagogical activities for primary school students, continuous phonics learning for primary school students and much authentic reading opportunities for primary school students. It's suggested that langauge instructors put more effort into phonics instruction which is proved critical to successful langauge learning among primary shcool learners.

\section{Acknowledgements}

This work is part of the project of On Cultivating and Developing Liaoning Scientific Foreign Language Talents with View to Bourdieu' Theory, the project of On Establishing Generative 
Mechanism of EFL Autonomous Learning Behaviors and Strengthening Development of Learning Field in Ubiquitous Learning Space, and the project of On Constructing Mechanism and Strategies for College English Autonomous Learning Abilities via Mobile Multimedia. This research was supported by the fund of Liaoning Planning of Philosophy and Social Science (Project No. L16CYY001), the fund of Liaoning Provincial Federation Social Science Circles (Project No. 20171slktyb-019), and the fund of the Thirteenth Five-Year Plan of Education Sciences of Liaoning Province (Project No. JG16DB013).

\section{References}

[1] Phonics. Retrieved from https://en.wikipedia.org/wiki/Phonics\#History_and_controversy.

[2] J. Smith, Introduction to Linguistic Theory and English Historical Linguistics.

[3] Z. Yu, An Application Study of Phonics in English Phonology and Vocabulary Teaching in Primary School, Jiangxi Normal University, 2011.

[4] NSW Department of Education and Training Learning and Development, Literacy Teaching Guide: Phonics. Sydney, New South Wales: NSW Department of Education and Training Learning and Development, Retrieved from the information on https://my.vanderbilt.edu/specialeducationinduction/files/2011/09/1-Literacy-teaching-guide-ph onics.pdf , 2009.

[5] National Institute of Child Health and Human Development(NICHD), Research Program in Reading Development, Reading Disorders, and Reading Instruction. Retrieved from http://www.ncld.org/ld-basics/ld-aamp-language/reading/the-nichd-research-program-in-readin g-development-reading-disorders-and-reading-instruction, October 10, 2010.

[6] Lizzy, The Research on Phonics Instruction of English Words Teaching in the Primary School, Chongqing Normal University, 2006.

[7] D. L. Schacter, PSYCHOLOGY, Catherine Woods, 2009.

[8] Cognitive Stages for Child Development, Retrieved from the information on http://www.learningrx.com/cognitive-stages-for-child-development.htm

[9] E. H. Lenneberg, Biological Foundations of Language, New York: Wiley, 1967.

[10]E. Bialystok, K. Hakuta, In other words: The science and psychology of second language acquisition, New York: Basic Books, 1994.

[11]M. J. Adam, Beginning to read: Thinking and learning about print, Cambridge , Massachusetts: Massachusetts Institute of Technology Press, 1990.

[12] National Inquiry into the Teaching of Literacy, Teaching Reading, Report and Recommendations, Australian Government, Department of Education, Science and Training, Canberra, 2005.

[13] Y. Center, Beginning reading: A balanced approach to reading instruction in the first three years of school, Allen and Unwin, Sydney, NSW, 2005. 